\title{
Spirituality and the memorialisation of the dead of the Durban Concentration Camps during the South African War (1899-1902) - a micro history
}

\author{
Prof Johan Wassermann \\ Faculty of Education \\ University of Pretoria, South Africa \\ Email: johan.wassermann@up.ac.za \\ Orcid id: https://orcid.org/0000-0001-9173-0372
}

Doi: https://doi.org/10.46222/pharosjot.102.118

\begin{abstract}
In this article, the spirituality and the memorialisation of the dead of the Durban Concentration Camps during the South African War (1899-1902) are analysed diachronically. As a study in micro-history, primary and secondary sources were used. Four clear memorialisation events were recognised: external British Imperial memorisation by means of obelisks that spiritually honoured Empire; Afrikaner Christian Nationalist memorisation that celebrated symbolic victory over the British Empire; rededication of the memorials in the inclusive spirit of the 'new' South Africa; and the partial abandonment of physical memorisation for remembering and honouring the dead in a virtual world. Each of these events offered its own seen and unseen forms of spirituality and understanding.
\end{abstract}

Keywords: South African War; concentration camps; spirituality; memorialisation; micro history.

\section{Introduction}

It has been argued that more ink than blood has been spilt on the South African War of 18991902 between the British Empire and the Boer Republics of the Transvaal (South African Republic) and the Orange Free State. ${ }^{1}$ Much of this ink has been spilt regarding the concentration camps created by the British Army for Boer and African civilians, especially women, children, and the elderly who were displaced by the war. These camps, however, also included 'hendsoppers' and 'joiners', that is former members of the Boer Commandoes who either surrendered or who actively joined the British imperial forces. It is generally accepted that 45 concentration camps were created for Boers during the conflict, housing more than 116000 inhabitants, and an estimated 115000 Africans were housed in 64 camps (Pretorius, 1999). These camps, segregated along black/white racial lines, were scattered over the southern African landscape, and were erected for multiple reasons, including to pacify the Boer commandoes; to punish civilians who supported the Boer commandoes logistically and otherwise; to clear the rural landscapes of the Boer Republics of people as part of the "scorched earth" military strategy; to accommodate civilians left destitute by the War; and to

\footnotetext{
${ }^{1}$ The South African War has, based on differing historiographical positionalities over time, been known by different names. These include, amongst others, the Anglo-Boer War, Boer War, South African War, English War, Gold War, and the Three-Year War. For this article, South African War is used to describe the conflict. This is a construction that gained popularity during the centenary commemorations of the conflict (1999-2002), and is in my view the most inclusive naming of the conflict as it names the combatants involved, as well as the geo-political region covered by the conflict.
} 
secure African labour for the British war effort. The concentration camps of the South African War are best remembered for the more than 26000 Boer civilians who died in these institutions, which left a deep scar on the Afrikaner psyche and identity. Large numbers of Africans also died in the mentioned camps but, owing to the racialised nature of the record keeping by the British authorities, there are no reliable statistics and mere estimations need to suffice (Kessler, 2012). In sum, the concentration camps of the South African War are synonymous with death on an industrial scale brought about by poor administration and rampant contagious diseases.

The largest concentration camp of the South African War was the Merebank Camp south of Durban in what was then the Colony of Natal. Merebank was created in September 1901, and was soon augmented by the opening of the Jacobs Camp in February 1902 and the Wentworth Camp in March 1902. The result was a system of three concentration camps south of Durban which was economically, logistically, and administratively easier to service than similar camps in the southern African interior because of its proximity to the Durban harbour and the railway line that passed these camps. The overall aim of the creation of these camps was to reduce the death rate. At its height, the Merebank Camp housed 8342 people in three sub-camps: Windermere and Grasmere, named after locations in the English Lake District, and Hazelmere in Buckinghamshire, England. At its height, the Jacobs Camp held 3080 and the Wentworth Camp 2982 people; this made a total of 14404 inmates at these camps (Wohlberg, 2002).

By the time the South African War ended with the signing of the peace treaty at Vereeniging, 454 deaths were recorded in the Merebank Camp, 49 in the Jacobs Camp, and 16 in the Wentworth Camp. A sum total of 519 deaths was recorded for the Durban Camps by the time the Jacobs Camp closed its doors in January 1903 (Wohlberg, 2002). The vast majority of the camp inhabitants who died, 77 per cent of those in Merebank, for example, were children. The deaths, of which about 20 per cent occurred in the various camp hospitals, were generally attributed to, amongst others, pneumonia, measles, tuberculosis, debility, and gastro-intestinal diseases. Many of these were contagious diseases for which the rural-dwelling Boers had little immunity. It is also worthy to note that five Africans and an unnamed Indian also died in the Merebank Camp. Burying the Durban Concentration Camp dead was generally undertaken by either dominees (ministers in the Afrikaans sister churches) or ouderlinge (elders in the Afrikaans sister churches) as according to the Calvinist Protestant Christian tradition of the Boers. Of the 454 deaths in the Merebank Camp, 22 were buried in the Anglican Church Cemetery at Isipingo, 19 at the Clairmont Cemetery adjacent to the Jacobs Camp, and the remainder at the Merebank Concentration Camp. The inmates who died in the Jacobs Camp were buried in the Clairmont Cemetery, and those who died at Wentworth in the eponymous cemetery. All considered, the death rates of the three Durban Camps, which were under the administration of the Natal colonial civilian authorities and specifically the Natal Burgher Camps Department, cannot be compare to the camps in the Transvaal and the Orange Free State that were under the administration of the British military until March 1901 (Wohlberg, 2002).

Unsurprisingly, the historiography of the concentration camps of the South African War is a controversial topic, and is described by Pretorius (2010), with reference to the white camps, as a debate without end. As such, there is a certain historical binary. On the one hand are those that are strongly influenced by a nationalist emotive memory of the camps who view the Boers who died as persecuted victims of British Imperialism for which an apology is needed (see, for example Raath, 1999). On the other are those historians who adopted a more historical disciplinary process to understand the camps in the context of the time as part of an imperfect strategy suffering from differing levels of administrative success (see, for example, van Heyningen, 2013). However, neither of these broad historiographical leanings have dwelt much on the memorialisation of the victims and how this relates to the spirituality of the seen and the unseen, the theme of the call for papers of this special edition. 
In this article, the spirituality of the seen and the unseen as it relates to the commemoration of the dead of the Durban Concentration Camps during the South African War is the focus. Specific emphasis is paid diachronically to key moments in the memorialisation for a period of more than a century.

\section{Theoretical and methodological anchors employed for the study}

Theoretically, this article drew, in a bricolage manner, on a number of ideas at the intersection of death, memorialisation, and gender. With reference to death, the idea of Heidegger (1962: 298 ) that death is a "social inconvenience, if not even a downright tactlessness" and, often a sign of weakness, was employed. This was done in reference to the fact that the Durban Concentration Camp inhabitants, who passed away in a non-combat situation, were a source of inconvenience to the British authorities and the Boers alike. Theoretically, this can be attributed to a patriarchal Boer society at the time that was divided into a male dominant culture and female subculture, with only the dominant culture being public and visible (Landman, 1996). The article also drew on the idea that memorials are erected to confer dominant selective meanings on space, and are essential for the articulation of the national politics of memory and identity through which the politically powerful set political agendas and legitimate their power (Bellentani and Panico, 2016). However, the relationship between memorials, collective memory, artistic values, identity, and power is complex and ever changing. Nevertheless, memorials are essentially political creations of an era which Mitter (2013), with reference to Hegel, describes as the gradual unfolding of the spirit towards historical selfknowledge, implying that this would end as a process when the spirit comes to understand itself completely. This unfolding can be described as the psychodynamics of rituals which, when performed publicly, serves to, amongst others, provide a sense of security and appreciation that is also important for resilience and coping (Hodge, 2000).

However, once erected, memorials become social properties, and users can reinterpret them in ways that are different or contrary to the intentions of the designers. My interpretation of the Durban Concentration Camp memorials was anchored by my self-identification as a white male in his late 50 s who holds a doctorate in the History of the South African War; I also have some maternal ancestors who are memorialised as victims of the Bloemfontein Concentration Camp. My "life-world" (Gadamer, 1989: 300-306) allowed me to create lenses to read the evidence related to memorialisation of the dead of the Durban Concertation Camps in order to make meaning. It must, however, be acknowledged that my subjective seeing will leave aspects unseen. Methodologically speaking, this article drew on micro-history to answer a large historical question (memorialisation of the dead) in a small space (the Durban Concentration Camps locations) in an attempt to understand the agency of the memorialisers (interpretation over time) (Joyner, 1999). In the process, primary and secondary historical evidence related to the Durban Concentration Camps was analysed in order to understand the preservation of memories of the deaths in the aforementioned camps up to the present. The evidence was engaged with in an intertextual connotative and denotative historical manner, whereby the various memorialisation events were read as relational and the latest readings are always influenced by earlier meaning-making processes (Dillon, 2007). More specifically, visual analysis, that is reading the memorials and associated visual images for meaning, was blended with conceptual analysis in which the changing meaning of the memorialisation of the dead of the Durban Concentration Camps was unpacked.

\section{Memorialising the dead of the Durban Concentration Camps}

As noted above, the dead of the Durban Concentration Camps were buried in various cemeteries. Apart from mounds of earth and possibly rough crosses indicating the graves, no evidence exists of self- or familial memorialisation for the three camps. This is in contrast to what happened to some of the dead among the Boer prisoners of war in India, for example. Here fellow male inmates create lasting stone cairns as memorials, and in certain instances 
relatives of the deceased had tombstones erected that were steeped in Christian symbolism (Wassermann, 2010). This in itself speaks to the collective inconvenience of the death of the women and the children under their care and their unheroic deaths that needed no personal or visible memorialisation in a patriarchal world.

Official memorialisation of the dead of the Durban Concentration Camps started in 1910, roughly seven years after the last inmate left. This in itself was symbolic in nature in that the former Boer Republics of the Transvaal and the Free State, and the British Colonies of Natal and the Cape, unified on 31 May 1910 to create the Union of South Africa. This was a geopolitical construction under the auspices and flag of the British Empire. The provincial authorities of the newly-created Province of Natal, the only of the four where white English speakers were in the majority, had the responsibility to oversee the erection of memorials to the dead of the Durban Concentration Camps. Within the British Imperial spirit of the time, only one design was possible, that of an obelisk. In fact, a manual existed for imperial use on the colour and design of obelisks that were erected as memorial stones (Wassermann, 2010).

The obelisk as the preferred memorial of the British Empire became popular as part of the Egyptian revival architectural style, and was adopted during the Victorian-era as a suitable monument. This was done because the obelisk came to be viewed as representing rebirth and connection between heaven and earth. More specifically, the obelisk symbolised resurrection, with the point on the top serving to break up the clouds and allowing the sun to shine through. Sunlight, it was believed, brought rebirth to the deceased (Carrott, 1978: 10-57). However, obelisks also had other attractive features. Carrott (1978) argues that obelisks were considered to be tasteful, with pure uplifting lines that could be erected in relatively small spaces and importantly, were less costly than large and elaborate monuments. Another appealing function was that it supposedly represented neutrality rather than overt religiousness. At the same time, it was seen as offering sacred sombreness and remembrance of the past, while presenting a unifying sameness rather than individualism. As such, obelisks were seen as a great leveller regardless of age, class, rank, status, or political conviction. The obelisk as a memorial was only disrupted by the different kinds of stone used in different regions. At the same time, obelisks were also associated by the British Empire with patriotism and ancient greatness associated with Ancient Egypt, Greece, Byzantuim, and Rome. However, the obelisk as a memorial also had other more contemporary meanings, namely as a phallic symbol of masculine power. It is also a symbol of victory without revealing the carnage involved. It therefore presents a public, cleaned-up image of war, while in a practical manner disposing of the dead and the sense of public loss (Hope, 2003).

The Natal provincial authorities, and more specifically the Public Works Department, decided on grey design no IV obelisks for the memorials for the Merebank Concentration Camp dead buried at Isipingo and at the Clairwood Cemetery. Twenty-two Boers who died in the Merebank Camp were buried in the Anglican Cemetery in Isipingo. They were memorialised with a grey obelisk on a white pedestal. On one panel was inscribed, in Dutch, the abbreviated names and initials and surname, age, and date of death of the victims that were buried here between 22 September and 22 October 1901. On a second panel was written in Dutch: "De monument is door de provinciale administratie opgericht ter gedaghtenis aan hen die in Isipingo Koncentratie Kamp Durban, gestorven zijn gedurende het tijdperk van de Zuid Afrikaanse Oorlog 1899-1902." What is telling is that none of the inscriptions were in English, and that the dead were inaccurately presented as being resident in the Isipingo Concentration Camp when no such camp existed. None of the graves appeared on the map of the cemetery.

On the obelisk memorial for the Jacobs Concentration Camp, the names and initials, surnames, and date of death of the inmates of the Merebank and Jacobs Concertation Camps buried in the Clairwood Cemetery appear on three panels. On a fourth panel the following inscription appeared in Dutch: "De monument is door de provinciale administratie opgericht ter gedaghtenis aan hen die in Jacobs Koncentratie Kamp Durban, gestorven zijn gedurende 
het tijdperk van de Zuid Afrikaanse Oorlog 1899-1902. En wier namen hierop vermeld staan." The last sentence was probability added to cover that fact that some of those who died in Merebank were initially buried at Jacobs. This was a strange oversight when considering that the war ended but a decade earlier.

The Merebank Camp victims who were buried in the camp cemetery were initially treated differently. The cemetery was to be overseen by the Public Works Department, but they were accused by the local Dutch Reformed Church of neglect. After a lengthy tug-of-war, the cemetery was transferred to the Durban Corporation in 1936. It was also during this time that a marble memorial obelisk was erected for the dead (Wohlberg, 2000). The obelisk erected at the site of the Merebank Concentration Camp Cemetery was a departure from those erected at Isipingo and Jacobs. This was in all probability done for practical reasons, namely to cover the large number of names of those who died in the camp. The obelisk is made from white marble with four cascading pedestals, allowing for 16 panels to be inscribed with names. On one panel appeared the following inscription in Afrikaans: "Opgerig deur die Natalse Provinsiale Administrasie ter gedagtenis aan diegene wat tydens die Anglo-Boereoorlog 19001902 in hierdie Kerkhof ter aarde gestel is." Replacing Dutch with Afrikaans refers to the fact that by then Afrikaans had evolved into an official language. The fact that the conflict is now called the Anglo-Boer War, and not the South African War as with the other two memorials, speaks to a historiographical change in the naming of the conflict. The remaining 15 panels on the memorial are inscribed with the first names, initials, and surnames of most of those who died in the Merebank Camp. In all probability for practical reasons related to space, no ages and dates of death were indicated, thus leaving this unseen. No memorial could be found for the victims of the Wentworth Concentration Camp.

What then does the three obelisk memorials for the dead of the Durban Concentration Camps reveal about the spiritually seen and unseen? What can be seen is that, in a contemporary reading, obelisks are male-orientated funerary architecture erected to commemorate the death of women and children. At the same time, the individual identity of the victims was for the most part subsumed by being inducted into empire by memorials produced on an industrial scale for small spaces. In death, the victims were thus received as members of the British Empire, and in so doing had a new imperial identity imposed on them.

What then was unseen? Foremost was the dead of the Wentworth Concentration Camp, since no obelisk was erected for them. Also absent was English as the language of Empire on the memorials, which signals a certain distancing and only a partial induction into Empire. Likewise, Christianity as the religion of the dead was absent and was usurped by the spiritual connotations between obelisk and empire. In the process of becoming an imperial citizen, any overt spritual linkinages to Christianity were not recognised. In its place came the spirit of being reborn into the greatness of the British Empire. As part of this rebirth, the obelisks masked the scale of the deaths in the Durban Concentration Camps, presenting a neat and sanitised image. Furthermore, not all those who died in the Merebank and Jacobs Concentration Camps were memorialised on the obelisks erected. As such, being inducted into the British Empire was, however, only reserved for those identified as white. Black victims of the Durban Concentration Camps did not have that honour bestowed on them. Consequently, the names of the Africans who died in Merebank - Kakejan, Klaas, Kleinbooi, Nip, and Marie Stell - along with the Indian baby, do not appear on the memorial, ostensibly for racist reasons (Wohlberg, 2002). Their deaths in the camps were truly inconvenient and thus had to remain unseen.

An individual who was also unseen was Ada Wallis, a teacher who came from Britain to teach in the Jacobs Concentration Camp as part of the Anglicisation process. She died of dysentery, but is not mentioned on the Jacobs Concertation Camp memorial. This is because she was not buried alongside the dead of the Jacobs Concentration Camp but in the West Street Cemetery in Durban in an individual grave adorned by a marble cross on a three-layered 
pedestal (Wohlberg, 2002: 287). Women like Wallis, constructed by Schoeman (2013: 1) as "angels of mercy", were already part of empire, and therefore did not have to be inducted by means of an obelisk.

The omnipresent power of the obelisk as a way to memorialise those who died in the concentration camps, including the Durban Camps, can be seen when considering that the centrepiece of the Women's Memorial in Bloemfontein is a 35-metre high obelisk. The obelik as a symbol of imperial prominence thus became the everlasting spirtual representation of the vicitims of the concentration camps of the South African War.

Following the memorialisation process after the South African War, the Durban Concentration Camps located in the most English part of the country, like many other painful aspects of the conflict, were officially backgrounded for reasons of nation building and reconciliation between the Afrikaners and English. Consequently, the South African War was not foregrounded in school history. However, the war and the camps were remembered by Nationalist Afrikaners wanting to restore a republic outside of the British Empire. An example of this was the centenary commemorations of the Great Trek in 1938, which took place in the vicinity of the Jacobs Concentration Camp Cemetery. As part of the commemorations, Goschen Street was renamed Voortrekker Street and it remained a mixed-residential area that became heavily industrialised from the 1960s onwards (https://www.fad.co.za/ Facts about Durban, 15.5.2021). Locally, the Durban Concentration Camps, and especially Merebank, were remembered by the Dutch Reformed Church in Durban (Wohlberg, 2000). Moves to return to the spiritual home of a Republic gained impetus when the National Party came to power in 1948, promoting racial segregation and apartheid policies. On 31 May 1961, South Africa became a Republic outside of the British Empire. The coming to power of the National Party and the creation of a Republic impacted directly on the Durban Concentration Camp sites. One of the key National Party Apartheid Acts, the 1950s Group Areas Act, designated Merebank as an Indian area, and "purpose-built houses replaced the poor settlements and by the late 1950's a reconstructed Merebank offered cheap houses for which the [Indian] purchaser had ten years to pay" (SA History online, Indian Community, 15.5.2021). The Merebank Cemetery subsequently had to be proclaimed a white area, and the Dutch Reformed Church and the Burgher Graves Commission took control of the Cemetery (Wohlberg, 2000).

The above coincided with unprecedented economic growth among Afrikaners, manifesting in shifts in patterns of consumption and attendant lifestyle changes and forms of status identification among Afrikaners (Grundlingh, 2008). The 1960s was thus an era of extreme politically nationalist Afrikaner self-confidence. Consequently, in the late 1960s, it was decided to alter the site of the Merebank Memorial. Under the national leadership of the Burgher Graves Commission it was decided to create a memorial garden at Merebank in order to prevent vandalism. The Burgher Graves Commission could only partially fund the project as part of a countrywide initiative, and local Afrikaner partners had to step up (Projek Gedenktuin, Wassermann collection, June 1968). Stanley and Dampier (2005) explain that this was the next layer of state- orchestrated and funded commemorative restoration, and had the support of the highest echelons of the National Party.

In many ways, the local Afrikaner community did take up the challenge, with Philna Ferreira, a local art teacher, playing a leading role. Ferreira designed a sarcophagus against a backdrop of a bas-relief image of a symbolic grave for angelic-like Boer women and children. Ferreira also designed an elaborate, colourful mosaic which symbolically depicted the Merebank, Jacobs, and Wentworth Camps: three praying Boer women in black mourning garb, a burgher on commando, children's graves, and a British soldier on the one side (Philna Ferreira ontwerper van sarkogaafpaneel en Mosaiektoneel Merebankonsentrasiekampkerkhof, 1968). The opening of the Merebank Memorial Garden took place on 10 October 1970, then a public 
holiday known as Kruger Day. ${ }^{2}$ By then a brick perimeter wall had been constructed to cover the site as a laager, with an elaborate gate, cloakrooms, amphitheatre, the above-mentioned mosaic scene, sarcophagus with backdrop, and three concrete tents symbolising the three camps all organised around the imperial obelisk memorial. Everything was enclosed within laager-like walls that cost large amounts of money to ensure that the surveying process, architectural plans, and construction took place to create an ordered culture in a chaotic African world (Stanley and Dampier, 2004).

The unveiling event was sponsored by, amongst others, Volkskas Bank, and was opened by a Bible reading and prayer. Present were dignitaries from local Afrikaans schools and the teachers' training college, Afrikaner cultural organisations, ministers in the Afrikaans churches, and the mayor of Durban. The idea was expressed that the memorial garden would be a "Heiligdom" for Afrikaner use which they should treasure and ensure its upkeep. The general events were a cocktail of Christianity and nationalism with phrases such as "... aan God en land en volk en taal getrou?", "... ons volkskiedenis aan Hom te wy", "... 'n huldeblyk aan die sulkes van Sy koningkryk", and "Trou aan God, ons bloed en aarde" (Merebank 10 Oktober 1970 containing program and hand-written notes - Wassermann collection). At this event, the Merebank Concentration Camp was linked distinctly and spiritually to Afrikaner nationalism and political power, whiteness, and protestant Christianity. The Christian National spirituality of the time was clearly discernible. The sentiments were summed up by the 81-year-old Mrs HC Erasmus who was a child in the Jacobs Concentration Camp: she said her blood boiled when she though back to that time, but was glad to visit the sites "onder " $n$ Republikeinse vlag" (Die Nataller, 1968).

The fanfare associated with the creation of a memorial garden at the Merebank Camp site was the Afrikaner spiritual high-water mark for the dead of the Durban Concentration Camps. The spiritual garden located in an Indian area, next to an international airport, freeway, and industry did not, however, become a haven for cultural, political, and religious ceremonies. The reality was that the creation of a memorial garden was but a brief hiatus against the unseen, namely, a physical abandonment by Afrikaners. In the 1970s and 80s, the area around the Jacobs Concentration Camp memorial became a truck stop and a football pitch in an industrial area. The Merebank Memorial Garden fared little better, with vandals and vagrants who did not share the spiritual sense of the terrain with Afrikaners running rampant, scaling the walls, defacing the mosaic, and taking up residence in the garden itself. As a consequence, funding was contemplated to do some restoration. In the end, the solution was to place razor wire on the perimeter wall while the garden remained locked for causal visits (Wohlberg, 2000).

By the time of the centenary commemorations of the South African War in 1999, much had changed in South African and consequently for the commemoration of the dead of the Durban Concentration Camps. White minority rule had ended in 1994, and apartheid and the racism that accompanied it had to be confronted. The spirituality of Afrikaner nationalism had to be visibly replaced by the adoption of ideas related to nation building, national identity, and civic nationalism (Resane, 2018). As a result, a national commemoration committee for the war was constituted to pursue the aforementioned goals. In Durban this meant the constitution of a representative local sub-committee for the commemoration of the conflict funded by the Durban Metro. A low-keyed commemorative event took place on 17 October 1999 for the dead of the Durban Concentration Camps. During the event, mainly a rededication of an old memorial, the small, predominantly white crowd listened to the history of the camps, poetry was read, and learners sang some songs. Wreaths were also laid at the imperial obelisk by Afrikaans and English cultural organisations (Evaldsson and Wessels, 2002). A small

\footnotetext{
${ }^{2}$ Kruger Day or Heroes' Day was a public holiday in South Africa from 1952 to 1994 . The day was celebrated annually on 10 October, the birthday of Paul Kruger, the former president of the Transvaal Republic.
} 
commemorative memorial plaque with captions in Afrikaans, English, and IsiZulu with basic information on the Merebank Cemetery was also revealed. This was part of a self-drive brochure to visit sites related to the South African War in Durban.

In all of this, the dead of the Durban Concentration Camps momentarily became a social convenience as they were used to give new selective meanings to the imagined ideas of nation building, rainbowism, and a shared conflict. This was done by rededicating the obelisk in the Merebank Concentration Camp, in a public ritualised spiritual manner, that was in line with the national political agenda of memory and identity (Bellentani and Panico, 2016) of the African National Congress and its allies. However, nothing was done, in the spirit of uniting black and white, to commemorate the forgotten deaths of black people in the Durban Concentration Camps. In this respect, the Durban camps were no different than other commemorative events in general (Nasson, 2000) that were held at other concentration camps. The exception was at Brandfort, where a memorial was erected to the black dead to ostensibly unite "black and white" as "common victims of Britain's brutality" (van Heyningen, 2013: 321-322). Consequently, some Africanist groupings considered the centenary quite irrelevant to the 'new' South Africa (Grundlingh, 2004).

After the centenary commemorations, the physical sites associated with the dead of the Durban Concentration Camps, except for the walled churchyard in Isipingo, were partially abandoned. This went hand-in-hand with the demise of sanitised urban segregation (Maylam, 1995), the dwindling numbers at Afrikaans schools and churches in Durban, a loss of political power, and the momentum of the 'New South Africa' as a project which had little spiritual sentiment for white suffering from a century ago, which was generally not viewed as part of a shared suffering. The physical "heilige" physical custodianship imposed on 10 October 1970 was for the most part never fully taken up in a landscape still affected by colonial realities such as the omnipresent obelisk memorials. The partial abandonment is offset by sporadic, spiritual-like physical clean-ups and maintenance (Sunday Tribune, 6.12.2009) of the Merebank Memorial Garden by volunteers, which serves to keep vagrants and vandals at bay.

The partial physical abandonment of the Merebank and Jacobs sites has been augmented by a migration to virtual sites of remembering. This aligns with what Grundlingh (2004) called a lively interest by Afrikaners in the centenary commemorations of the South African War, while steering clear of overt political interpretations of the conflict by the new state. The consequence was a digital mobilisation. The powerful presence of, for example, the Merebank Concentration Camp in the spiritual realm of the cyber world is borne out by the fact that a recent Google search yielded 5640 results in 0.36 seconds. This included a Facebook page with 853 likes and 866 followers which shows photos of clean-up operations done during 2017 and 2018. This demonstrates a blend of physical and virtual commemoration. However, it seems that cyberspace has offered a new liberating reality for a new audience to commemorate the dead of the Durban Concentration Camps by means of genealogical sites, as well as a range of history and political sites where people are able to share their thoughts and feelings freely. As a result, a range of new selective meanings of physical spaces of memorialisation arose in virtual spaces that articulated the politics of identity and memory in a manner that no longer directly needed the powerful dominant political agendas of the past. This novel cyber relationship with the dead of the Durban Concentration Camps signalled a new era of memorialisation accessible by anyone with access to the internet; they can then perform the psychodynamics of the rituals of memorialisation in a private yet public manner. As a consequence, the dead of the Durban Concentration Camps are honoured by means of technology, and are therefore seen through the ideas and emotions of, a larger and more diverse audience than ever before. In giving life to the memorialisation of the Durban Concentration Camp dead in this manner, the distinct possibility exist that it might in future take away the need to visit or care for the physical sites associated with the physical sites themselves. By means of this, there is the possibility that the online world will serve to transcend the physical spirituality associated with the dead of the Durban Concertation Camps 
by taking it into cybernetic realm and a different, deeply diverse spiritual understanding of memorialisation.

\section{Conclusion}

In this micro-history, the seen and unseen spirituality and the memorialisation of the dead of the Durban Concentration Camps during the South African War (1899-1902) were analysed diachronically. In the process, the shifts in memorialisation evident at the Durban Concentration Camps were read against dominant socio-political ideologies and changes in commemorative practices.

These memorialisation practices can be organised around four major spiritual events, each with its own seen and unseen phenomena. Firstly, the externally imposed physical memorialisation by imperialism by means of obelisks after the war. Secondly, an Afrikaner Christian Nationalist revival in the 1960s. Thirdly, the centenary commemorations which attempted to bring the Durban Concentration Camp dead and its memorials into a shared South African history, and fourthly, the post-centennial era in which the physical memorialisation was partially abandoned for virtual cybernetic ones. In the most recent stage of memorialisation, the social inconvenience of honouring the dead started to fade. Along with this, in a post-colonial world, ideas of external colonialisation (British) and internal colonisation (apartheid as part of Afrikaner Nationalism) as encapsulated in granite and marble are being replaced by new dominant selective meanings about space related to the national politics of memory, cyberspace, identity, and power. It is therefore quite possible that the psychodynamics of rituals performed publicly in the past for the dead of the Durban Concentration Camps will not take place physically again on the scale that they did previously. Instead, this will in all probability be subsumed by a cyber-reality that will provide a new sense of security and appreciation that will stand in contrast to what these events offered in the past in a more tangible manner. This is because the ways in which we remember the dead are not fixed - even if our monuments endeavour to arrest the past indefinitely. Instead, public memory and the related spirituality, like history itself, is irrevocably shaped by the vicissitudes of an ever-changing present. What will, however, remain for a long time are the durable obelisks of empire.

\section{References}

Bellentani, F. \& Panico, M. (2016). The meanings of monuments: toward a semiotic approach, Punctum, 2(1), 28-46.

Carrott, R.G. (1978). Egyptian Revival: Its Sources, Monuments and Meaning 1808-1858, Berkeley, University of California, 10-57.

Dillon, S. (2007). Music, Meaning and Transformation, Cambridge: Cambridge Scholars.

Die Nataller, (1968). Onder 'n Republikeinse Republiekeinse vlag.

Evaldsson, A.K. \& Wessels, A. (2002). The Anglo-Boer War Centennial: a critical evaluation, Journal for Contemporary History, 27(3), 125-144.

Facts about Durban, Letter by Ken Rigney, Available online at https://www.fad.co.za/ Accessed 14.5.2021.

Gadamar, H. (1989). Truth and Method, New York: Bloomsbury. 
Grundlingh, A. (2004). Reframing remembrance: the politics of the centenary commemoration of the South African War of 1899-1902, Journal of Southern African Studies, 30(2), 359-375.

Grundlingh, A. (2008). "Are We Afrikaners Getting too Rich?" Cornucopia and Change in Afrikanerdom in the 1960s, Journal of Historical Sociology, June/Sept, 143-165.

Heidegger, M. (1962). Being and Time, New York: Harper and Row.

Hodge, D.R. (2000). Spirituality: Towards a theoretical framework, Journal of Religion \& Spirituality in Social Work, January, 6-7.

Hope, V. (2003). Trophies and tombstones: Commemorating the Roman soldier. World Archaeology, 35(1), 79-97.

Joyner, C.W. (1999). Shared Traditions: Southern History and Folk Culture, Urbana, University of Illinois, 1.

Kessler, S. (2012). The Black Concentration Camps of the Anglo-Boer War, 1899-1902, War Museum of the Boer Republics, Bloemfontein.

Landman, C. (1996). The Piety of Afrikaner Women: Diaries of Guilt, Pretoria: UNISA Press.

Maylam. P. (1995). Explaining the Apartheid City: 20 Years of South African Urban Historiography, Journal of Southern African Studies 21(1), 28.

Merebank containing program and hand-written notes, Wassermann collection, 10 October 1970.

Mitter, P. (2013). Monuments and memory for our times, South Asian Studies, 29(1), 159-167.

Nasson, B. (2000). Commemorating the Anglo-Boer War in post-apartheid South Africa, Radical History Review, 78, 149-165.

Pretorius, F. (1999). The Anglo-Boer War 1899-1902, Cape Town: Struik.

Pretorius, F. (2010). The white concentration camps of the Anglo-Boer War: a debate without end, Historia, 22(5), 34-49.

Philna Ferreira ontwerper van sarkogaafpaneel en Mosaiektoneel Merebankonsentrasiekampkerkhof, Wassermann collection, 1968.

Projek Gedenktuin, Wassermann collection, June 1968.

Raath, A.W.G. (1999). The British Concentration Camps of the Anglo-Boer War, 1899-1902: Reports on the camps, Bloemfontein: War Museum.

Resane, K.T. (2018). Statues, symbols and signages: Monuments towards socio-political divisions, dominance and patriotism?, HTS Teologiese Studies / Theological Studies, 74(4), 4895.

Schoeman, C. (2013). Angels of Mercy - Foreign Women in the Anglo-Boer War, Cape Town: Random House. 
Stanley, L. \& Dampier, H. (2005). Aftermaths: post/memory, commemoration and the concentration camps of the South African War 1899-1902, European Review of History, 12(1), 91-119.

Sunday Tribune, 6.12.2009, Keeping our heritage alive.

van Heyningen, E. (2013). The Concentration Camps of the Anglo-Boer War. A Social History. Johannesburg, Jacana.

Wassermann, J. (2010). The erection and maintenance of monuments to Boer prisoners of war in India 1902-1948, South African Journal of Cultural History, 24(2), 73-98.

Wohlberg, A.U. (2000). The Merebank Concentration Camp in Durban, 1901-1902, MA, University of the Free State, Bloemfontein.

Wohlberg, A.U. (2002). The Durban Concentration Camps: Merebank, Wentworth, Jacobs, in J. Wassermann and B. Kearney, A Warrior's Gateway - Durban and the Anglo-Boer War, Pretoria: Protea, 272-303 